\title{
Precious and base metal crustal fertility during construction of the Eastern Pontides arc, NE Turkey
}

\author{
FRANCOIS TURLIN ${ }^{1}$, ROBERT MORITZ ${ }^{1}$, OHRAN \\ KARSLI $^{2}$, SERDAR KESKIN ${ }^{3}$, SAFAK UTKU SÖNMEZ ${ }^{1}$, \\ ABDURRAHMAN DOKUZ ${ }^{4}$ AND FARUK AYDIN ${ }^{5}$ \\ ${ }^{1}$ University of Geneva \\ ${ }^{2}$ Recep Tayyip Erdoğan University \\ ${ }^{3}$ General Directorate of Mineral Research and Exploration, \\ Eastern Black Sea District Office, Trabzon, Turkey. \\ ${ }^{4}$ Gümüşhane University \\ ${ }^{5}$ Karadeniz Technical University \\ Presenting Author: francois.turlin@unige.ch
}

The composition of the continental crust has evolved since the early-Earth from mafic to felsic in response to a switch from vertical to horizontal tectonics, that has led to the initiation of subduction at ca. 3.0-2.8 Ga and recycling of the continental crust. Since that time, juvenile crust was progressively added to continents, and its composition is a combination of mantle and older crustal components. Similarly, the metal endowment and fertility of the continental crust are controlled by these processes, especially when considering base and precious, including $\mathrm{Cu}$ and $\mathrm{Au}$, which can be both concentrated up to economic grades in porphyry and epithermal deposits in subduction- and postcollision arc settings.

In this study, we propose to decipher the role of successive recycling and continental crust growth cycles controlling metal endowment and fertility during arc construction and postcollisional evolution. Our study is focused on the Eastern Pontides, NE Turkey which belongs to the Tethyan orogenic belt and which recorded several successive subduction and postcollision crustal recycling events during almost 500 m.y., i.e. since the dislocation of Gondwana to the Alpine orogeny. This arc is characterized by a high concentration of $\mathrm{Cu}(-\mathrm{Mo})$ porphyry and $\mathrm{Au}$ and base metal epithermal deposits, mostly related to the latest stages of arc construction during the Late Cretaceous and Cenozoic. This protracted tectono-magmatic history and spatiotemporal association with metal deposits raises several questions relative to the origin of the metal endowment in metallogenic belts. Does the early sterile vs. recent fertile character of the Eastern Pontides reflect unfavourable physico-chemical conditions and/or a lack of or negligible metal enrichment in the sub-continental lithospheric mantle during crustal growth and arc evolution prior to the Late Cretaceous? Our ongoing study investigates these questions using zircon U-Pb-Hf-O-trace element data of granitoids of the Eastern Pontides, which are associated with successive subduction and post-collision events. These data will allow us to decipher the relative sources of the granitoids, their nature, age and potential contaminations through time. In addition, we will document the relative contributions of distinct crustal segments involved in the genesis of ore deposits of the study area. 